\title{
노
}

LAWRENCE LVEFMOAE LABORATORY

university of Caflomia/Nivermora, Cathornta

\section{PRODUCTION OF INTENSE NEGATIVE ION BEAMS}

\author{
J. E. Osher \\ F. J. Gordon
}

G. W. Hanilton

August 18, 1972

\begin{abstract}
This repart was prepared as an account of work aponsored by the United Strtes Govornment. Neither the United Stateg nor the United States Atomic Energy Commlssion, nor any of their employees, nor any of their contractors, subcontractors, or their employees, makes any warranty, express ar Implied or assumes any logal lisbllity or responslbility for the accuracy, complotenses or uatefuiness of any informution, apparatus, product or procoss disclosed, or represents that its use would not infringe privately owned rights.
\end{abstract}

This paper was prepared for presentation at the

2nd International Ion Source Conference,

Vienna, Austr1a, Septenber 11-16, 1972

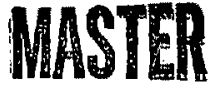


Production of Intense Negative Jon Beams

John E. Osher, F, J, Gordon, G. W, Hamilton

Lawrence Livermore Laboratory, University of Callfornia

Livermore, California 94550

\section{INTRODUCTION}

Negative ion beams have long.been of interest for various nuclear physics and accelerator uses. Recently, it has becone evident that very intense $D^{-}$beams would be desirable for long-range controlled fuston applications - either for efficient high-energy neutral bean production 1,2 or for direct injection 3 into a fusion reactor for fueling or heating purposes. Preliminary experiments are reported on intense beam formation both by direct extraction of negative ions fron a calutron type 4 of ion source and by use of multiple electron plckup by a low-energy $D^{+}$bean from a multiple aperture scuree 5 pasing through an alkali metal charge exchange cell such as cesium. 6,7

PREDicted aNd EXPERTIENTAL PERFoRMANCE

Direct extraction of negative ions from a plasula 1s.clearly linited by the relative negative ion population and the local density. Nost of the cross sections involving negative ion production or destruction $\left[e, g, \mathrm{H}_{2}\right.$ $+\mathrm{B}+\mathrm{H}^{-}+$etc.j are known, but optimun conditions are difficult to attain because of the many coupled parameterg, plasma interactions, and surface effaces. Our expectations were that the $H^{*}$ composition would be $\leq 58$ of the avallable $\mathrm{H}^{+}$density oven under the best of experimental conditions.

The calutron (ór gyclotron). type of ion source was chosen as the hatural geometry for use as a negat lve lon source bacause ton extraction perpendicular to the waginet ic field allows separation from the electrons. 
However, the electrons still must bo handled on a sultably located and biased collectar because they drain by $\vec{E} \times \vec{B}$ drift and would represent a majo: problem at full extraction energy.

The experimental geometry used with the calutron source is shown in

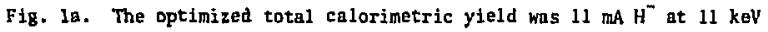
(total normal drain for $\mathrm{H}^{+}$operation of $\sim$ A) from a $5.7-\mathrm{cm}$ by $3.2-\mathrm{kmm}$ slot. Df this total, $1.2 \mathrm{~mA}$ was avallable as a focused \pm 1.4 deg beam. The best performance was achieved using a $0.17 \mathrm{~mm}$ arc-to-slot separation. The usc of traces of $\mathrm{NH}_{3}$ with the source gas appeared detrimental. Judging by the above yleld, the relative $\mathrm{H}^{-}$plasm composition appears to be $\leq 1 \frac{1}{4}$ under our conditions, thus limiting the expected performance.

Indirect agative beam production depends upon the avallability of intenge low-energy ion beans and the relative cross sections for electron attachment to form negative ions. Hork in controlled fusion research for the Baseball II experiment ${ }^{B}$ had produced a steady state multiplo aperture source (MATS) ${ }^{5}$ yielding over $1 \mathrm{~A}$ of nominally $\mathrm{t}^{+}$(defined below) at $1.5 \mathrm{keV}$ in a $6.3-\mathrm{cm}-d i a m b t e r$ beam ( $532 \mathrm{~mA} / \mathrm{cm}^{2}$ averaged, including 468 transparency) with a divergence of approximacely \pm 4 deg. Recent cross section measurements $s^{6,7}$ for $\mathrm{H}^{+}$(or $\mathrm{D}^{+}$of equal velocity) in alkali vapors yield the thick zarget equilibrium fxaction $F_{a x}^{-}$show in Table 1 . To obtain high effietency With the low-energy MATS, we chose to use cesium. The predicted negative lan yield as a function of cosium coll thickress for incident $D^{+}$or $D^{0}$ beams is shown in Fig. 2, for a cell thickness of $2 \times 10^{15}$ cesium atoms $/ \mathrm{cm}^{3}$ the Table 1. Predicted equilibrium $\mathrm{D}^{-}$fraction. ${ }^{6}$

\begin{tabular}{lcc}
\hline Vapor & Optimum $\mathrm{D}^{+}$energy, keV & $F_{\infty}^{-}$ \\
\hline $\mathrm{Na}$ & 7 & 0.12 \\
$\mathrm{~K}$ & -3 & 0.14 \\
$\mathrm{Cs}$ & 1.5 & $0.21 \pm 0.04$ \\
\hline
\end{tabular}


calculated $y^{i e l d}$ is 0.2 .4150$, since conversion is through $D^{0}$ formation, the $\mathrm{D}^{*}$ can be swept out and the $\mathrm{D}^{0}$ beam passed through subsequent cesiun cells, for higher net conversion to $D^{*}$ (limited by scattering an estimated - 0.2 deg per cel1, 2 and complications in $\mathrm{D}^{-}$optics).

The experinental arrangement for the initial $D^{-}$tests is shown in Fig. 1b. Neasurements were made of the \pm beam components as a function of coll thickness (ceslum oven tomperature). The total nominal $p^{+}$bean available through a 5ystem of $6.3-\mathrm{cm}$-diameter cell apertures on a 6.3 m-cmdiameter target located $95 \mathrm{~cm}$ from the sourca wes $200 \mathrm{~mA}$ calorimetric. This yielded a maximum total $\mathrm{D}^{-}$signal of $50 \mathrm{~mA}$ electrical or $42 \mathrm{~mA}$ calorimetric (explained in Tabis 2). Figure 3 shows comparative traces of the incident and emergent species in arbitrary units for mass calibration purposes, The auplitudes of the raw deta require substanctal correction for analyzer sensicivity (background gas, charge exchange, stray magnetic flelds, and secondary emission coofficjent]. Table 2 sumarizes the

Table 2. Detalled wass and energy analysis of noininal incident $\mathrm{D}^{+}$ beam and emergent products.

Incident nowinal $\mathrm{D}^{*}$ beam composition, keV

Emergent bean [optimum cesium)

$$
\begin{array}{r}
110 \mathrm{~mA} \mathrm{D}(1.5) \\
30 \mathrm{~mA} \mathrm{D}_{2}^{+}(1.5) \\
6 \mathrm{~mA} \mathrm{D}_{3}^{+}(1.5) \\
-40 \mathrm{~mA} \mathrm{D}^{0}(1.5) \\
-7 \mathrm{~mA} \mathrm{D}_{2}^{0}(1.5) \\
-14 \mathrm{~mA} 0^{0}[0.75)
\end{array}
$$

$$
\begin{aligned}
& -32 \mathrm{~mA} \mathrm{D}^{-}(1.5 \mathrm{keV}) \\
& -18 \mathrm{~mA} \mathrm{D}^{-}(0.75 \mathrm{keV}) \\
& -1 \mathrm{~mA} \mathrm{D}^{+}(1.5 \mathrm{keV}) \\
& \text { trace } \mathrm{D}^{-}(0.5 \mathrm{keV}) \\
& \text { trace } \mathrm{DD}^{-} \\
& 149 \mathrm{~mA} \text { equiv } \mathrm{D}^{0} \text { and } \mathrm{D}_{2}^{0}
\end{aligned}
$$

Total nominal $\mathrm{n}^{+}$boam $200 \mathrm{~mA}$ equiv.

Total $50 \mathrm{DA} \mathrm{D}^{-}$electrical and 42 IA calorimetric (as part of $\mathrm{D}^{-}$not at $\left.1.5 \mathrm{keV}\right)$ 
calculated yield is 0.2 . Also, since conversion is through $\mathrm{D}^{0}$ formation, the $\mathrm{D}^{-}$can be swept out and the $D^{D}$ beam passed through subsequent cesium cells, for hlgher net conversion to $0^{-}$(limited by scattering an estimated "0.2 deg per" cel1, 2 and complications in $0^{-}$optics).

The experimental arrangement for the initial $0^{-}$tests is shotn in Fig. 1b. Measurements wero made of the \pm beam components as a function of coll thlekness (ceslum oven temperature). The total nominal $\mathrm{D}^{+}$beam available through a system of $6.3-\mathrm{cm}-\mathrm{diameter}$ cell apertures on a 6.3-cmdiamecer target located $95 \mathrm{~cm}$ from the source was $200 \mathrm{~mA}$ calorimetrit. This yielded a maximum total $\mathrm{D}^{-}$signal of $50 \mathrm{~mA}$ electrical or $42 \mathrm{~mA}$ calorimetric (explalned in Tablo 2). Figure 3 shows comparative traces of the incident and emergenc species in arbitrary units for mass callbration purposes. The anplitudes of the raw data require substantial corraction for analyzer sensicivity (background gas, charge exchange, stray magnetic fields, and secondary emission coefficient). Table 2 sunuarizes the

Table 2. Detalled mass and erergy analygis of nominal incident $B^{+}$ beam and emergent products.

Incident nominnl $\mathrm{D}^{+}$beam composition, keV

Emergent beam (optimum cesium)

$$
\begin{array}{r}
110 \mathrm{~mA} \mathrm{D}^{+}(1.5) \\
30 \mathrm{~mA} \mathrm{D}_{2}^{+}(1.5) \\
6 \mathrm{~mA} \mathrm{D}_{5}^{+}(1.5) \\
\sim 40 \mathrm{~mA} \mathrm{D}^{0}(1.5) \\
-7 \mathrm{~mA} \mathrm{D}_{2}^{0}(1.5) \\
-14 \mathrm{~mA} \mathrm{D}^{0}(0.75)
\end{array}
$$

$$
\begin{aligned}
& -32 \mathrm{NA} \mathrm{D}^{-}(1.5 \mathrm{keV}) \\
& { }^{-18} \mathrm{IA} \mathrm{D}^{-}(0.75 \mathrm{keV}) \\
& -1 \mathrm{MA} \mathrm{D}^{+}(1.5 \mathrm{keV}) \\
& \text { trace } 0^{-}(0.5 \mathrm{keV}) \\
& \text { trace } \mathrm{DD}^{-} \\
& 149 \mathrm{~mA} \text { equiv } D^{0} \text { and } D_{2}^{0}
\end{aligned}
$$

Total nomingl $0^{+}$beam 200 na equiv. Total $50 \mathrm{~mA} \mathrm{O}^{-}$olectrical and 42 mA calorimotric (as part of $0^{-}$not at $1.5 \mathrm{keV}$ 


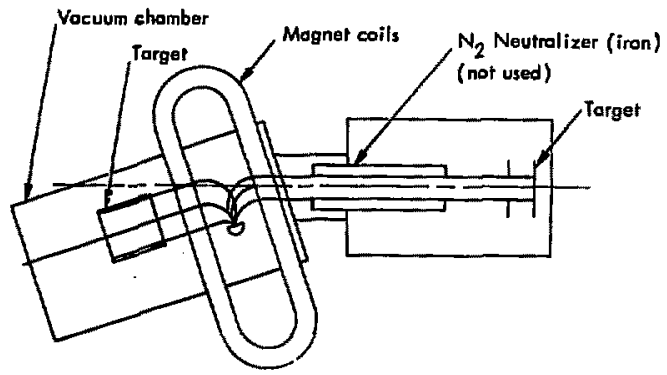

a. Direst extraction from a calutron-type ion source

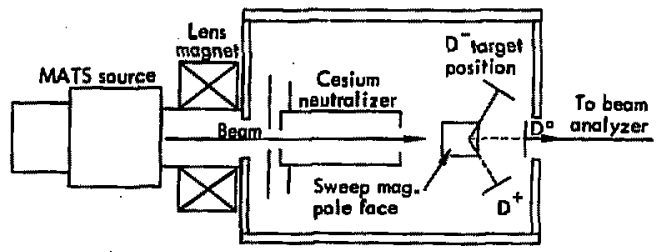

b. Cesium vapor cell for electron attachment after magnetic focusing. Extraetion

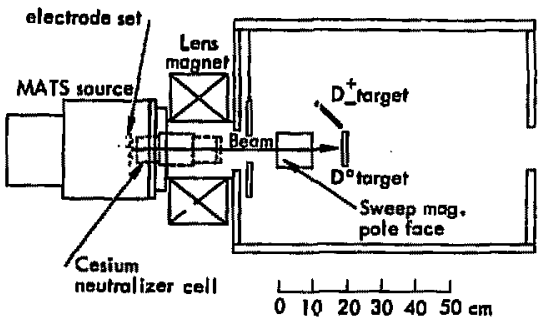

c. Cesium vapor cell for olectron attachment without magnetic facusing.

Fig. 1. Test stands for negative ion production. 


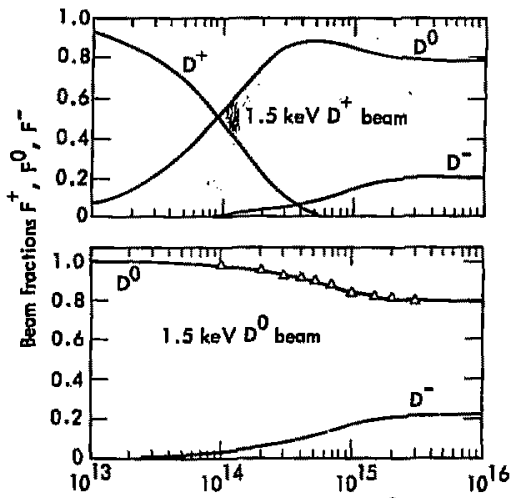

$\pi(n \ell) C s-a t a m s / \mathrm{cm}^{2}$

Fig. 2. Bean fractions $\left(\mathrm{F}^{+}, \mathrm{F}, \mathrm{F} \rightarrow\right.$ computed as functions of cesiun cell thickness for $1.5 \mathrm{keV}$ incident $\mathrm{D}^{+}$and $\mathrm{D}^{0}$ beams.
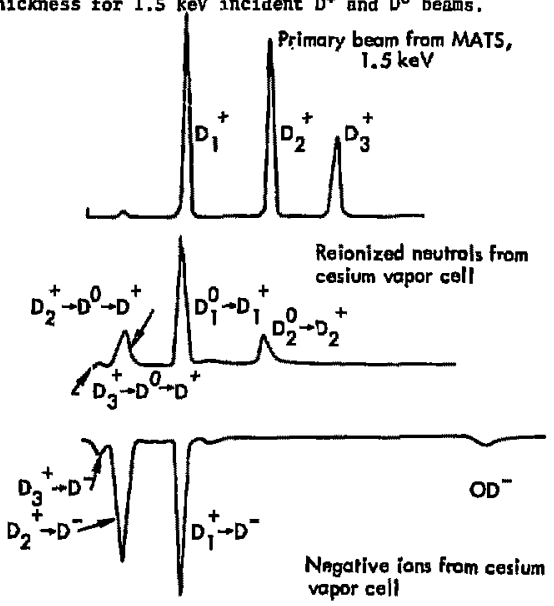

Fig. 3. Magnetic analysis of neutra1s and negative tons produced in a cesium vapos cell at $1.5 \mathrm{keV}$ (raw data). The horizontal scale is proportional to $(\mathrm{m} \cdot \mathrm{E}) \mathrm{l} / 2$. 